\title{
Teaching as Altered Knowledge: Rethinking the Teaching Practice with Michel De Certeau
}

\author{
Federico Rovea ${ }^{1}$ (D)
}

Accepted: 30 June 2021 / Published online: 14 July 2021

(c) The Author(s) 2021

\begin{abstract}
Michel De Certeau's scholars have rarely explored the pedagogical potential of the French thinker's thought. This paper aims at reconstructing the question of the teaching practice in De Certeau's works and, building on such reconstruction, it proposes a possible 'heterological' comprehension of teaching. Moving from an early writing dealing specifically with the teacher's identity, the paper shows how the famous dyad of strategies and tactics exposed in The practice of everyday life can be usefully applied to teaching and studying and helps further elaborate the question of teaching. From this analysis, the teacher will emerge as the owner of a strategic knowledge that, if he wants to teach, needs to be altered by the uncanny and tactical presence of the student. Teaching will finally be shown as the practice of alteration of knowledge operated by the other of such knowledge, namely, the student. In such alteration of knowledge lies the potential of a heterological comprehension of teaching.
\end{abstract}

Keywords Teaching $\cdot$ De Certeau $\cdot$ Practice $\cdot$ Educational theory $\cdot$ Everyday $\cdot$ Otherness

\section{Introduction}

In these times of progressive standardization of teaching and of continuous attempts at making teaching a simple reproduction of the existing social values, the conscience of the need for a 'rediscovery of teaching' seems to grow among scholars (Biesta 2016). Gert Biesta is certainly among the firsts to underline the need to re-discover the value of teaching against the over-attention given to 'learning'. Indeed, he proposes to put aside the values imposed on teaching by the broader society and by the neoliberal market in order to 'give teaching back to education' (Biesta 2005; 2009; 2013). This means to foster a 'virtuebased education' (Biesta 2013) rooted in the sensibility of the teacher towards the specific educational value of a given situation, and not relying only on relations of cause-effect (as the so-called evidence-based education). Others have described the defense of teaching in different ways, but working on the same necessity. Vlieghe and Zamojski have, for

Federico Rovea

federico.rovea@phd.unipd.it

1 Department of Philosophy, Sociology, Pedagogy and Applied Psychology (FISPPA), Università Degli Studi Di Padova, Via Beato Pellegrino 28, 35137 Padova, Italy 
instance, proposed a 'things centered pedagogy' (Vlieghe \& Zamojski 2019; Hodgson 2017) as a way to put at the core of the teaching practice the object of teaching itself (be it, for instance, a novel, music, a foreign language or carpentry) and in so doing giving the students the possibility to 'begin anew' with those objects. These kinds of proposals clearly aim at cutting off the interferences of society on teaching. Teaching is here considered as a pure presentation of something valuable to the younger generation, who can then decide freely what to do with it. ${ }^{1}$ Other important proposals see the possibility to conceptualize the practice of teaching as 'making something public' or as 'suspending' the usual significance of something in order to study and eventually criticize it (Simons \& Masschelein 2010; Masschelein \& Simons 2013; Lewis \& Daniel 2015; Lewis 2009). Again, given the present state of neoliberal education, we can foresee in such thought the need to value the 'renovating' and 'freeing' aspects of teaching. Furthermore, Thoilliez (Thoilliez 2019) proposes to use the metaphor of 'craftmanship' as framed by Richard Sennet to describe the aim of teaching as transmitting the value of 'doing a good job for its own sake', not pursuing other objective than that of a job well done. In Thoillez proposal we can read, once again, the claim for the autonomy of teaching, done 'for its own sake' and freed from pre-determined outcomes. Finally, we shall not forget the effort completed by the Marxist-inspired pedagogists to conceptualize teaching as a process of liberation from alienation (McLaren, 2004; Macrine, 2010; McLaren 2020). Actually, in this latter case the theorists put forward a precise outcome of teaching - the construction of a socialist society-which can be criticized as a simple substitution of the neoliberal imposition with another, although opposite, obligation. Nevertheless, we can interpret these framing of the question of teaching as another attempt at going back to teaching to free it from the contemporary societal demands.

What can be identified as the common goal of these very different concepts? Obviously this is not intended to be a complete review, but rather a collection of significant examples of a cultural necessity: the necessity of elaborating a non-reductionist theory of teaching as an independent activity, free from societal demands, from politicization, from psychologization and so forth.

In this article I try to add a little-known voice to this ongoing debate by elaborating some insights coming from Michel De Certeau's writings on the question of teaching. De Certeau's conception of teaching as a practice of 'alteration' of knowledge-teaching means, according to De Certeau, bending one's own knowledge to the necessities of the student -, which I will now discuss, represents an original contribution to the debate around teaching. Michel De Certeau's scholars have rarely focused on the pedagogical legacy of the French thinker. ${ }^{2}$ Nevertheless, De Certeau was an attentive and interested

\footnotetext{
1 This conceptualization of teaching is inspired by the work of Hanna Arendt (see in particular Arendt 1977).

2 Significant exceptions can be found in Séradin, 2016, 2017, Jacomino, 2016, Saltmarsh, 2015, Zoletto 2012. Yves Séradin's book Penser avec Michel De Certeau. Une pédagogie du quotidien (2016) is currently the only available monography exploring De Certeau's educational ideas (although the text is mainly focused on the idea of 'everyday' and its educational consequences and it does not consider other moments of De Certeau's intellectual production). Séradin (2017) has also underlined the deep connection between De Certeau's thought on education and the Jesuit tradition. Differently, Jacomino (2016) and Saltmarsh (2015) have engaged two more specific aspects of De Certeau's thought on education: the former maintains the importance of death and finitude in De Certeau's conception of education, while the latter explores the idea of 'practice' as a useful tool to design educational policies. Finally, Davide Zoletto (2012) has argued that De Certeau's unique intellectual style is helpful to think of possibilities of creative pedagogical interventions in difficult situations.
} 
reader of educational theories: he discussed in several occasions Bourdieu and Passeron's La reproduction (De Certeau 1971, 1988), he extensively read Paulo Freire's works (De Certeau 1988, 1997) and observed with interest Ivan Illich's foundation of the Intercultural Center in Cuernavaca (De Certeau 1969). Furthermore, he was interested in the French pedagogical debate of the Sixties and Seventies. He was especially intrigued by how the first waves of immigration in France had an impact on the schooling system (De Certeau 1968b) and he gave a cycle of seminars on education and everyday life at the University of Geneva in 1977-1978 (De Certeau 1979). In addition, his major work The practice of everyday life is deeply influenced by the pedagogical experiments of the controversial educator Fernand Deligny, who described the walking of autistic children around the community he managed as lignes d'erres ('wandering lines'). ${ }^{3}$ Finally, De Certeau has reflected in a dense paper on his activity as a university teacher, focusing on the specificity of the practice of the seminar as a way to 'alter' one's own research practice and to 'be altered' by the other's knowledge (De Certeau 1978).

As previously stated, in this article I propose a reconstruction of De Certeau's thought regarding the teaching practice. Starting from an early article published in the book L'étranger ou l'union dans la difference (2010) and describing the teacher's act of 'giving voice' to the student, I try to elaborate the reciprocal positions of the teacher and the student using the conceptual tools of strategy and tactics, proposed by De Certeau in The practice of everyday life (1988). From such reconstruction, the student emerges as the other of teaching, some point of ungraspable exteriority to which teaching itself is directed, and which constantly alters the teacher's knowledge. Following the course of this argument, I will conclude by proposing a possible heterological comprehension of teaching, based on the relationship of reciprocal exteriority and 'alteration' of teacher and student.

\section{Anna's First Words: the Newcomer as an Uncanny Presence}

Anna is starting to talk. She is just sixteen months old, but she already moves towards you and tries to talk to you. Is it a question, an expression of love or the narration of a success? It is impossible to know [...] Your word comes back to you from the place it has awakened, and you already do not recognize it in this hidden meaning poem: born from a love, now it reveals to you the existence of your child (De Certeau 2010, $45)^{4}$

In an article first published in 1969, entitled Giving the speech, ${ }^{5}$ Michel De Certeau describes the experience of being in front of an infant who is pronouncing her first words. Those words are incomprehensible, a collection of sounds that do not make any sense for the adult listener: the adult has tried to teach the baby some words, but the response s/he

\footnotetext{
3 See De Certeau 1988: XVIII; Deligny 2017. The concept of tactics, which will be further explored in this paper, is deeply influenced by Deligny's educational work with children. Tactics, just as children's wanderings, are described by De Certeau as cluttered trajectories whose aim is to build spaces of free expression.

4 All quotations from De Certeau 2010 are personally translated, as an English translation of this text is not yet available.

5 An interesting parallel can be found between this title and the emphasis put by Freire on the pedagogical necessity of 'speaking a true word' (Freire 2005, 87). Both authors share the conviction that at the core of a true educational process lies the possibility for the educated to speak for him/herself. Nevertheless, as I will further develop, while according to Freire such goal is reached via a dialogical process, De Certeau seems more incline to underline the conflictive and destabilizing nature of the process.
} 
gets is some ungraspable sound. This is, according to De Certeau, not only the sign that the baby needs more time to master the language, but rather it is an experience that reveals a specific structure of the relationship between different generations ${ }^{6}$ : the 'dispossession'(De Certeau 2010, 63) of the adult's speech. The child is not-as expected-just trying to repeat the adult's words, but is sort of inventing her own ones, ${ }^{7}$ putting together some heard sounds to express herself in an original way. While pronouncing those senseless sounds, Anna is already emerging as a subject, distinct and unrecognizable from the adult: she is breaking the laws of language that someone is trying to teach her in order to speak with her own voice.

Anna is expressing, without the mediation of any specific content, the pureness of her subjectivity. She is, in a sense, already showing that her existence, as part of a new generation, entails a form of subversion of the adult's knowledge about the world. She is already 'other' from the adult. Such experience can be described in the terms of the Freudian 'uncanny' (Freud 1991) ${ }^{8}$ : something familiar, as the voice of a child, that turns out scary, mysterious, and even macabre. One of the experiences of the 'uncanny' described by Freud is the one of the 'robot', so to say: seeing a statue that is supposed not to be alive and that suddenly moves gives the felling of 'uncanny', of a mysterious subversion of one's expectations towards an object of the world. Something very similar happens to Anna, as the adult expects her to repeat his words and to be docile to his teachings, while she-not refusing the adult's teachings but bending them, in a way-steals the speech and tries to speak for herself.

Furthermore, according to De Certeau, the child's words are disturbing because 'the emergence of the child coincides with that of a new world' (De Certeau 2010, 45). Such a new world that emerges with the child's original subjectivity is something unknown, unpredictable for the adult's knowledge, just as incomprehensible are Anna's first words. A disturbing alterity - although not an absolute alterity, in the Lévinasian sense-is, so, the form taken by the child asking for some form of education and at the same time 'taking the speech'.

This condition, from the adult's point of view, is so described as a 'dispossession' (De Certeau 2010, 63) of the speech:

\footnotetext{
${ }^{6}$ In this text De Certeau writes without further clarification about 'adults', 'educators' and 'teachers' (De Certeau 2010:45-46). Anna's example is intended to present some features of the educational relationship between generations in a general sense. The author's aim is not to make specific claims about the role of teachers, of parents or of educators as different figures but he aims at proposing an example useful to think about the educational process in general.

${ }^{7}$ This description echoes in a later text exploring the phenomena of glossolalia, seen as an event that 'permits saying to take place' (De Certeau 1996, 38). De Certeau points at glossolalia and at the baby's sounds as foundational events, in the sense that both are pre-linguistic expressions that open the possibility for a language to exist - they 'begin' a language without really being part of it.

${ }^{8}$ The influence of psychoanalysis, in the Freudian and Lacanian versions, is almost omnipresent in De Certeau's works (for instance De Certeau 1987; 1992): De Certeau was an active member of the Parisian École Freudienne (Freudian School) founded by Jacques Lacan, along with other eminent scholars like Julia Kristeva and Cornelius Castoriadis. Although in the article Giving the speech Freud is not directly quoted, the way the relationship between adult and infant is described - the infant as 'other' or 'unrecognizable face' and the 'dispossession' of the adult's speech—can suggest a Freudian inspiration and justifies the reference to the Freudian 'uncanny'.
} 
Under these conditions, it seems like the educator ${ }^{9}$ has nothing more to say. He is no more giving the speech to others: they are taking it (De Certeau 2010, 46).

This kind of 'dispossession', nevertheless, is not absolute. De Certeau is not pointing out a failure of the adult's educational intentions (in this specific case, the intention of teaching an infant to talk). The kind of 'taking the speech' at work here is not a subversion happening once for all, that puts the adult out of the game to leave the space for an anarchic self-expression of the child. This 'dispossession' looks more like an interruption of the adult's voice, a form of self-expression of the child that breaks the flow of the adult's speech revealing its ultimate powerlessness. ${ }^{10}$

Consequently, De Certeau continues, the most common feeling experienced by adults when confronting the young will be fear:

When he [the educator] claims to arm the kids for their future, they actually disarm him; after complaining that 'they do not listen to nobody', he ends up asking himself: 'in the end, what do I have to tell them?'. He foresees a void, which ultimately is in himself. He steps back, because such uncertainty is inconsistent with his confidence (De Certeau 2010, 50)

Adults fear the dispossession of their own word, they fear being speechless in front of their children. The fear described by De Certeau is not the tension every adult feels when confronted to young people, but is the conscience that s/he could have nothing valuable to transmit them, ${ }^{11}$ because in the end it will be up to them to take the stage and to speak for themselves. The educator's fear is not accidental, rather it is the fundamental feeling that goes with the consciousness of the radical impotence of his educational activity. He fears not being in control of the educational process.

Uncanny as the fundamental experience of 'being in front of a young' and fear as the feeling that accompanies it seem to be some key features of the adult-young relation identified by Michel De Certeau as a form of dispossession of speech. Such dispossession is not absolute, but nevertheless lies at the core of the educational process.

Using De Certeau's own terms, Anna's behavior can be further described as a tactic or as 'la perruque'. ${ }^{2}$ These terms refer to the act of 'taking advantage of the space of the other', just as Anna takes advantage of the sounds heard to express herself in an original way. To further clarify this, I will now move to a more mature text-The practice of everyday life - to present the interplay between strategy and tactics as useful to further

\footnotetext{
9 Again, the author is not making claims about educators as professionals (nor is he doing the same about teachers, parents etc.) but he is using an example every person who works with the young can recognize $\mathrm{him} /$ herself in. See footnote.

${ }^{10}$ In the years 1968-1969 De Certeau also published several articles reflecting on the events of May'68, which were collected in a volume significantly named The Capture of Speech and Other Political Writings (De Certeau 1997b). The same logic described with Anna's example is put at work there: the student riots are an 'event of language': the students take up their own words in a society that expect from them a passive behavior. This event has not resulted in a radical political transformation, as many of the old institution have rapidly re-gained their previous role of power after the period of the riots. What has really changed, according to De Certeau, is the common awareness that something 'other' has happened and so it is possible to happen again. The word is again taken by the adult's institutions but is evident that a 'capture of speech' is always possible, and that the young can speak for themselves.

11 This statement reminds in some way the affirmation by Biesta taking up Derrida's words, when he writes that teaching is 'to give something that you don't have' (Biesta 2013, 54).

12 Untranslatable expression often rendered in English as 'poaching'.
} 
understand the adult-young relationship. Even though these concepts are meant to describe everyday practices, their use will help us better clarify how to understand the nature of the adult-young relationship: indeed, the same patterns of thought found in The practice of everyday life were already at work in De Certeau's early works just explored.

\section{Teaching Strategies and Learning Tactics}

The practice of everyday life (1988)—which is probably the best-known work by Michel De Certeau - can be summarized as an attempt at describing the nature of everyday practices. A sort of reversed double of Michel Foucault's Discipline and Punish, De Certeau's book tries to "identify [...] the "operations or patterns of actions" the users invent in their everyday activities to develop an original space of creativity not subordinate to the dominant order' (Biancotti 2004, 2). ${ }^{13}$ Foucault's attention was captured by the microtechniques of power producing docile subjects, while De Certeau-who was nevertheless an interested reader of Foucault's writings - was rather intrigued by the everyday invisible operations put in place by the supposed docile subjects to elude power structures (see Bocchetti 2015; Resweber 2007; Biancotti 2004).

In this context, 'tactics' is a conceptual tool developed to describe the altering and emancipative nature of everyday activities, emerging as the other of the codified practices called 'strategies'. As De Certeau claims:

A tactic is a calculated action determined by the absence of a proper locus. No delimitation of an exteriority, then, provides it with the condition necessary for autonomy. The space of a tactic is a space of the other. Thus it must play on and with a terrain imposed on it and organized by the law of a foreign power. It does not have means to keep to itself, at a distance, in a position of withdrawal, foresight, and self-collection [...] It does not, therefore, have the options of planning general strategy and viewing the adversary as a whole within a district, visible, and objectifiable space. It operates in isolated actions, blow by blow. It takes advantage of the "opportunities" and depends on them, being without any base where it can stockpile its winnings, build up its own position, and plan raids (De Certeau 1988, 36-37)

According to De Certeau, most of the everyday activities are describable as tactics because they are spontaneous, they are non-codified and because they happen 'in the space of the other'. This latter expression refers to the social space as increasingly dominated by power relationships. In particular, De Certeau is referring to the social reality of the consumer's society, where the subjects are considered just passive receivers of products designed by someone else. In such a space dominated by power relationships, everyday tactics operate differently, 'blow by blow', building micro-spaces of resistance. The tactical subjects, De Certeau continues, cannot 'stockpile their winnings'. The nature of tactical agency is that of the instant - the kairòs - and of the present moment: tactics do not extend their agency over a continuous time, but they just open a temporary alternative space of action. In this sense, tactics are not just opposed to strategies in an equal confrontation, but they 'take advantage' of the strategies moment by moment. The creativity of tactics is instantaneous and ephemeral.

\footnotetext{
13 Personal translation. In the original text: 'De Certeau intenta individualizar-tomando sus propias palabras-las "operaciones o esquemas de acción" que los usuarios o receptores "inventan" en su quehacer cotidiano para desarrollar un espacio original de creatividad no subordinado al orden dominante'.
} 
Against a passive consideration of subjects, De Certeau aims at identifying the active and creative operations consumers invent to affirm their subjectivity. For example, he writes on television viewers the following:

[...] the analysis of the images broadcasted by television (representation) and of the time spent watching television (behavior) should be complemented by a study of what the cultural consumer 'makes' or 'does' during this time and with these images. The same goes for the urban space, the products purchased in the supermarket, the stories and legends distributed by the newspapers, and so on (De Certeau 1988, XII).

In the 'space' of the broadcasted programs, the viewer tactically watches something and avoids something else, retains some images and forgets some other, taking advantage of what the television offers.

Underlined the tactical nature of everyday activities, on the other hand De Certeau describes the strategy as...

the calculation (or manipulation) of power relationships that becomes possible as soon as a subject with will and power (a business, an army, a city, a scientific institution) can be isolated. It postulates a place that can be delimited as its own and as the base from which relations with an exteriority composed of targets or threats (customers or competitors, enemies, the country surrounding the city, objectives and objects of research etc.) can be managed (De Certeau 1988, 35-36).

Strategies are all those practices supported by a knowledge or a theory (in this sense they are codified), whose subject has a precise and definite identity (although not necessarily individual) and which through the practice itself separate an inside and an outside space. To recall the example already quoted, a broadcast company acts—mostly—strategically: it is a recognizable and definite agent that acts following a plan, and through the activity of broadcasting distinguishes the space of the producers (inside) and the one of the spectators (outside). The public has, again, a tactical role because it has no decisional power over what is broadcasted on tv but it is only active in the sense that it can decide 'what to do' with the images it sees. Strategy and tactics, it's worth stressing this point, are not meant to be all-embracing concepts, neither they are reciprocally exclusive (see Siapkas 2015 and Frow 1991): it is to say, not every action is necessarily describable in terms of strategy or tactics. Furthermore, one practice can be described in strategical terms in a specific situation and in tactical terms in another. What is fundamental for Michel De Certeau is the reciprocal relationship of a strategy and a tactics: no one can be visible without the other, or, better said, the normative and the heteronormative moments are inseparable (Bocchetti 2015) and reciprocally necessary. A tactic is visible only 'in the space of the other' and every strategy is altered by the presence of tactical movements.

Now, going back to the question of teaching, we may ask ourselves if the interplay between strategy and tactic is helpful to understand more deeply the relationship between teaching and studying. It may seem obvious to think of teaching in terms of strategy and of studying in terms of tactics ${ }^{14}$ but, as I will now show, the consequences of such choice are not obvious at all.

\footnotetext{
14 This is also the argument followed by Jacomino (Jacomino 2016) in reading De Certeau from a pedagogical point of view, although with a different focus.
} 
The teacher responds to the features of strategy in two senses: firstly, he is the owner of a knowledge upon which s/he acts ${ }^{15}$ (a knowledge the student is supposed not to possess, which comprehends both the disciplinary knowledge and the pedagogical knowledge); secondly his practice of teaching clearly distinguishes him/her as a subject from the students. In addition, the teacher chooses the activities and the modalities of the practice of teaching/ studying, so s/he is in the position of setting the space in which the others move.

On the other hand, the student can be considered a non-definite subject, ${ }^{16} \mathrm{~s} /$ he moves 'in the space of the other' taking advantage of the opportunity such space offers. Taking advantage is, for instance, what Anna does when she 'invents' her own words using the sounds she hears-pure momentaneous self-expression without a plan: the emersion of an unexpected other within the limits of a knowledge (in this case, the language). What Anna does is metaphorically every student's behavior: when introduced to a knowledge, a student tries to retain something that can be useful for him, often in a completely different sense from what the teacher means. The student, we can add, 'alters' the teacher's knowledge in unexpected ways.

Furthermore, according to De Certeau, but I will return on this, 'taking advantage' of the situation and taking the floor to speak for oneself can be seen as the final outcome of teaching.

Back to Anna's example, some further considerations can be made. Firstly, the strategic knowledge of the teacher seems in a way necessary. Even though the goal of teaching is for Anna to speak for herself, she will not be able to do it if, at first, someone would not have taught her some language. The teacher's knowledge acts as the stage on which Anna takes the speech: she needs to be introduced to some cultural tool she can use to express her subjectivity. As previously stated, tactics are not visible outside of the space of a strategy and the educational use of these concepts seems to confirm it. In De Certeau's words:

One day they [the students] will, after having settled down in the teacher's voice say in their own terms what the teacher tried to tell them (De Certeau 2010, 46)

Secondly, it is equally necessary from the side of the student to act as a-so to say-blind fleck in the teacher's knowledge. I do not mean this in a constructivist sense, meaning that every student needs to build a personal or individual sense out of knowledge, but I want to point out that every student represents an interruption in the teacher's knowledge, an event, in the sense of some totally unexpected alterity showing itself (see Biesta 2013, 139-141). When the student becomes able to speak for himself, in a certain sense, he interrupts the meaning transmitted by the teacher to affirm something else, re-combining the teacher's words into his/her own discourse. In other words, every kind of teaching is directed to

\footnotetext{
15 This affirmation can be considered valuable even if knowledge is considered, as Hanna Arendt did (Arendt 1977), in the sense of a responsibility to introduce the newcomers in the existing world. The teacher is supposed to know the existing world, the pupil does not.

16 This claim can be obviously criticized. What I intend here is not to deny the necessity of taking into account the personal differences between students in the practice of teaching, but rather I want to stress the point that teaching entails an unavoidable direction towards a group; a group that, nevertheless, does not constitute a totality (using a Lévinasian word). In this sense the student can be considered—so to say—an undefined subject, in between the individual and the collective. See for instance Masschelein and Simons 2013 on the teacher's attention during lesson, directed to everyone and no one in particular. In the same direction goes Michel Serres (Serres 2014) when he describes his character Thumbelina as a figure of the younger generation which is at the same time subjective and collective. These authors, among others, have reflected on the necessity to counterbalance the huge attention given in recent educational discourses to individualized learning with a re-consideration of the collective or communitarian aspects of education.
} 
someone who will receive the teaching in an unpredictable way, maybe even reversing the sense of it.

Before moving further, a clarification seems to me important. This discussion around De Certeau's conception of teaching and studying as a two-character interplay (teacher and students) does not mean to bypass the contemporary debates around other forms of teaching and learning. More contemporary and, so to say, community-based approaches to teaching-i.e. cooperative learning, service learning, BYOD etc.-may seem to be already far from the strategy-tactics model. Obviously, De Certeau's reflections should be read with historical and contextual awareness. ${ }^{17}$ Nevertheless, I intend this discussion as a clarification of some fundamental aspects of teaching and studying per se, before (logically, not chronologically) their actual practice. The concepts of strategy and tactics are useful thinking resources that can be applied to very different practices and I maintain that their discussion can represent an interesting occasion of self-reflection for practitioner of very different teaching approaches. ${ }^{18}$ A strategic and a tactical pole-and their interplay-can be identified in potentially every teaching practice, thus enriching the teacher's awareness of her/his role.

Back to teaching-strategies and learning-tactics, a contradiction seems to emerge. Between the teacher-strategy and the student-tactics there seem to be a fracture, an infinite distance of roles, a real contradiction. Consequently, does this comprehension of the teacher-student relationship fall into the 'manipulative' ${ }^{19}$ way of teaching, where the teacher's duty is to transmit a monolithic (strategic) knowledge and the student will eventually oppose to affirm his/her own personal identity and knowledge? As I will now show returning on the article Giving the speech, De Certeau offers a way to understand the teachingstrategy that does not fall neither into the manipulative nor in the student-centered vision. The author offers an alternative path by recognizing the fundamental otherness between teacher and student and by identifying teaching as a very peculiar kind of strategy. Finally, it seems necessary to stress a point: the distinction between strategy and tactics-even more when applied to teaching and studying-does not imply any form of moral judgment. De Certeau is not claiming that strategic agency represents some sort of immoral or oppressive behavior while tactics should be seen as the pure rebellion of the oppressed. Certainly, describing tactics—once again, using a psychoanalytical language — as the Freudian 'return of the repressed' is more appropriate than claiming a 'rebellion of the oppressed'. These two terms are interpretative tools to read social relationships and, as already underlined, they are reciprocally necessary_-just as there cannot be a 'return of the repressed' without a personal psyche built exactly on that repression. Nevertheless, it is also certain that De

\footnotetext{
17 We have to remind, for instance, that most of De Certeau's reflections on education are rooted in the critical cultural milieu brought by May'68 and the Second Vatican Council. The need for a complete rediscussion of the educational models at that time is one of the main sources of inspiration of the French Jesuit. See De Certeau 1997b; 2010.

18 A very similar case is that of Hanna Arendt's writings on education, still today widely discussed (see Arendt 1977; Korsgaard 2020; Swillens \& Vlieghe 2020; Gordon 2001). Arendt's reflections are still of great interest today because they address some fundamental philosophical themes around education: these kinds of questions matter potentially for every educational practitioner, even if today's teaching methods are obviously very far from the one's Arendt had in mind.

19 See Biesta 1998 for a precise contextualization and clarification of this term.
} 
Certeau's interest is much more attracted by the tactics of the weak than by the strategies of power. ${ }^{20}$

\section{Teaching as a Paradoxical Strategy, Studying as an Alteration of Knowledge}

Teaching, as I have outlined, can be interpreted in terms of strategy, while studying can be interpreted in terms of tactics. Nevertheless, it is essential to stress once more that the relationship between strategies and tactics is of reciprocal necessity rather than of reciprocal exclusion: a tactic is not visible without a strategy, and there is a constant exchange between the two. In addition, it is not possible to describe once and for all an act as a strategy or as a tactic. Consequently, the description of teaching as a strategy should not be considered as a rigid conceptualization: as it will be further shown, it is possible to describe some aspects of teaching as tactical and some elements of studying as strategical. Considering tactics and strategies in their unavoidable entanglement helps us considering the complex and unstable nature of the relationship between teaching and studying.

Moving further, De Certeau describes the role of the teacher as follows:

[The teacher] reinterprets his tradition depending on his interlocutors. [...] $\mathrm{He}$ adjusts it to their abilities; but especially their needs organize the teaching. Teaching does not arrive at the end of a process that from the scientist goes down to the communicator, or from the poet to the anthology. [...] The teacher will rewrite for them all the books he has stored, thanks to that form of rewriting ${ }^{21}$ that will make them his neighbors (De Certeau 2010, 55-56).

It is interesting to notice here that De Certeau refers to the teacher as someone who is the representative of a tradition (absolutely consequent with a strategic interpretation of teaching), but who is also called to a 'rewriting' of such tradition. Far from a conception of teaching as a transmission of knowledge, De Certeau describes here the teacher as the one who knows a tradition but 'rewrites' his knowledge for the other. He does not make the content of knowledge simpler to make it understandable; he engraves the other into the body of his own language. We could also say that the teacher's job-differently from the scientist's or the expert's-is to bend knowledge to the necessities of those who lie outside of that knowledge: teaching remains a strategy, but a strategy which is structurally marked by the expectance of the other.

Quoting the expression by Jacomino (Jacomino 2016, 111), teaching can be described as a 'paradoxical strategy'. Indeed, while strategies are pointed out by De Certeau as acts aiming at repressing the other ${ }^{22}$ to constitute a totality, teaching —although not losing its strategic character-is a strategy always concerned with the necessity of making space for the other. In other words, teaching is a strategy open to his exteriority, open to its own negation. As De Certeau puts it, the teacher will.

\footnotetext{
20 This is evident in The practice of everyday life (De Certeau 1988) but also in De Certeau's writings about Foucault's books. De Certeau was very critical about Foucault's excessive attention to power strategies, often neglecting the movements of micro-resistance (De Certeau 1987; Marks 1999; Bocchetti 2015).

21 Italics and English in the original.

22 A famous example is the city mapping as a strategy which, to produce a totally visible image, eliminates the infinite plurality of everyday practices. See De Certeau 1988, 91-111. Another useful example is the above quoted Freudian consideration of 'repression': the repression of some desires and impulses is necessary according to Freud to constitute a stable Self.
} 
Let his own disappearance be a part of his pedagogical planning, as a way that even those who need to be educated must follow to overcome the fear blocking them on the threshold of adult life (De Certeau 2010, 51)

For such strategy to be put in practice, the student's alterity must be preserved. The student needs to be considered as a non-predictable exteriority, safeguarded in his 'own right to existence' (De Certeau 2010, 50) which also means in his right to alter knowledge. In chapter 5 of The writing of History (De Certeau 1992) De Certeau offers another useful example of what he means with 'alteration' of knowledge. This text is a study on the Récit de voyage by the XVI century French explorer Jean de Léry, concentrated specifically on the writing activity of the explorer who tries to organize on paper (and to understand and explain) the habits of the inhabitants of a Brazilian village. The writing seems to be perfectly logical and all-encompassing, but something eludes its rationality: the voice of the savages singing during a celebration-impossible to write or describe-marks the presence of otherness in the space of Léry's writing. The voice alters Léry's writing and tactically insinuates the writing to mark the existence of an exteriority. The student performs the same role into the teacher's strategy: it marks a disturbing exteriority which represents at the same time the final aim of the strategic act itself (understanding the savages in the first case, giving knowledge to the young in the second).

Another example of 'alteration' of knowledge, more directly linked to education, is the one of reading/writing (De Certeau 1984, 131-154; 165-177). De Certeau describes writing as a significative strategical activity especially in Western European culture (indeed named as 'scriptural economy'): the act of writing begins with a blank page, a space at complete disposal of the writer who will organize thoughts and experiences into a unitarian text. The multiple inspirations the author follows are finally reduced and organized into one single narration by one single writer. Differently, reading shows some tactical features. While reading it is possible to skip some pages, to meditate on one line, to underline some expressions, to retain some elements or characters and to forget some other. In other words, if the text represents a strategical pole the reader represents a tactical one, that acts as an alteration of the unity of the text. The reader-just as the student described above-is the addressee of the text and, at the same time, s/he alters its sense.

Considering writing as a strategical activity brings some important consequences on how we conceive education: the 'blank page' in front of which the student is put when learning to write suggests that studying has to do with a position of control, domination and ultimately with a movement of reduction of the multiple to one. It is interesting to notice that some contemporary scholars (i.e. Vlieghe 2014; 2016; Alirezabeigi et al. 2020; Dussel 2018; Serres 2014) have taken up and discussed the metaphor of the 'blank page' (even if without referring directly to De Certeau) in relation to the new digital learning environments. Considering that screens-with their capacity to contain multiplicity, for instance in the form of multimedia texts-are in a way taking the place of paper pages, do we have to re-consider the pertinency of the metaphor of the 'blank page'? In a sense, screens are a very helpful tool towards a 'paradoxical strategy' in teaching, as they allow enough space for the student to alter and rewrite the teacher's texts and teachings. In addition, the screen is nothing like a 'blank page' the student must fill, but it is always full of information to navigate through. At the same time, we should not forget that new and very pervasive forms of strategic reduction-algorithmic control, for instance-are put in practice via digital devices. The digital allows some interesting forms of 'paradoxical strategies' in teaching but it also gives space to unprecedented forms of repression of the student's alterity. 
In conclusion, teaching as a 'paradoxical strategy' appears in De Certeau's writings as the activity of adapting the existing knowledge-received from the past- to the necessities and questions of the present generation, who alters and transforms it. This act includes the contradictory poles of preservation and alteration, in an undecidable relationship: passing the tradition and, at the same time, passing it in a way that leaves enough space for the students to 'capture the speech' into it.

\section{Conclusions: Towards a Heterology of Teaching}

I have started with the article Giving the speech, where De Certeau describes the experience of the teacher in front of a child as uncanny, because of the emergence of the ungraspable subjectivity of the child that eludes the rules of language. I have then moved to a discussion regarding book The practice of everyday life, in order to interpret the teacher and the student in terms of strategy and tactics. From such discussion, the teaching emerged as a paradoxical strategy - a strategy concerned with the arrival of the other - and the student as an alteration of the teacher's knowledge.

In the introduction, I have tried to sketch out the necessity of a 'rediscovery of teaching' that seems to be widely shared among educational scholars. De Certeau's vision of teaching can be a significant contribution to such discussion.

Firstly, De Certeau safeguards the autonomy of teaching from other forms of cultural transmission (mass communication, scientific publication etc.) but at the same time he understands teaching with the same intellectual tools used to analyze other 'everyday practices'. Teaching is at the same time a very peculiar practice and a part of a broader group of practices that share some features.

Then, teaching as a strategy includes a content and a relationship. One of the points of absolute originality in De Certeau's way of thinking is the capacity of not resolving the tensions into one pole or another: teaching, for instance, is not essentially about something (a content) or essentially about a personal relationship but about the alteration of both. Studying, similarly is not about assimilating or opposing a tradition, but about opposing - so to say-while assimilating. Teaching-like other everyday practices—can be described as a field of tensions between forces that emerge one from the other, producing alterations and innovations.

Finally, such conception of teaching can represent a possibility to safeguard both the necessary transmission from the teacher and the intellectual freedom of the student. Indeed, conceiving teaching as a paradoxical strategy strongly affirms the necessity of a mature figure introducing the young to an existing tradition, but as well it safeguards the unpredictable subjectivity of the student. The teacher must, following this argument, keep his/ her role of introducing the youngest to the existing world, but with a specific concern for the otherness of the students which obliges him to rewrite constantly his/her knowledge. If we see 'learnification' (Biesta 2005) as an effacement of teaching, and on the opposite side 'banking education' (Freire 2005) as an effacement of the student, then the 'paradoxical strategy' of teaching may be an unstable and situated way to affirm both in their mutual, necessary and unstable relationship.

As a conclusion, we can describe De Certeau's particular approach to teaching and studying by using the term 'heterological'. 'Heterology' can be considered-as underlined by Luce Giard (Giard 1991), the most prominent living De Certeau's scholar - the final aim of all De Certeau's intellectual production and, obviously, his pedagogical reflections are part of it: 
For De Certeau, to interrogate each figure of rationality without privileging a stable center of perspective from which to contemplate their succession was to forbid the establishment of an exempted position from which their totalization could be produced. It would thus be impossible to give a definitive form to the science of the Other, and it would be necessary as well to replace this first enterprise with one, more modest, of illuminating the formality of practices without delineating an ordering principle (Giard 1991, 217)

Heterology represents the attempt made by De Certeau of paying attention to the multiple, to the repressed and obscure elements in every rational project. De Certeau always tried to observe and describe the interplay between the one and the other in every rational figure (i.e. strategies and tactics; Jean de Léry and the indigenous population; the teacher and the student etc.), without privileging one of the two poles but showing their constantly changing (and altering) relationship. ${ }^{23}$ Heterology, in this sense, can be described as the project of a 'science of the other' aimed at observing how the other constantly affects and alters the one, so to say. Even if, as stated, heterology was De Certeau's main project, it cannot be considered an actual philosophical proposal to discuss or a concept to be applied in different forms of research; it rather represents a sort of invitation to be attentive to the other and to its emergencies in every intellectual undertaking. We can finally ask, following once again De Certeau: can a heterological comprehension of teaching be possible and useful for today's educational research?

Going back once again to the initial claims about a so called 'rediscovery of teaching' in today's educational research, some final considerations can be made. As stated in the introduction, many educational scholars are proposing a rediscovery of teaching-although in very different framings - as a counterbalance to the neoliberal and individualistic discourse that reduces teaching to a 'facilitation of learning' (Biesta 2005). De Certeau's heterology represents a useful contribution to this ongoing discussion. Firstly, considering the reciprocal alterity and the unstable interplay between the teacher and the student can help to avoid an excessive formal conceptualization of teaching. Every framing of the practice of teaching runs the risk of becoming rigid and of excluding some aspect of such a multifaced act: considering teaching 'heterologically' can prevent a similar stiffening of thought. Secondly, considering teaching as a 'paradoxical strategy' can help safeguarding at the same time the role of the teacher as representative of a tradition to transmit and the equally necessary freedom of the student in receiving the teaching. The tactics of learning always haunt the strategies of teaching, creating a movement that should be considered in its peculiar, unstable and promising nature.

Funding Open access funding provided by Università degli Studi di Padova within the CRUI-CARE Agreement.

Open Access This article is licensed under a Creative Commons Attribution 4.0 International License, which permits use, sharing, adaptation, distribution and reproduction in any medium or format, as long as you give appropriate credit to the original author(s) and the source, provide a link to the Creative Commons

\footnotetext{
${ }^{23}$ See for instance Sandywell 2004 on the heterological framing of everyday life and Giard 1991 about heterology and the study of travel narratives. We can recognize De Certeau's attention towards how the repressed (the everyday tactics and the indigenous voices, in the two examples here quoted) affects identity (strategical practices and the traveler's identity) at work on very different topics (such as, indeed, the study of everyday practices and the research on modern travel writings).
} 
licence, and indicate if changes were made. The images or other third party material in this article are included in the article's Creative Commons licence, unless indicated otherwise in a credit line to the material. If material is not included in the article's Creative Commons licence and your intended use is not permitted by statutory regulation or exceeds the permitted use, you will need to obtain permission directly from the copyright holder. To view a copy of this licence, visit http://creativecommons.org/licenses/by/4.0/.

\section{References}

Alirezabeigi, S., J. Masschelein, and M. Decuypere. 2020. The agencement of taskification: On new forms of reading and writing in BYOD schools. Educational Philosophy and Theory. 52 (14): 1514-1525.

Arendt, Hannah. 1977. The crisis in education. In Between past and future: Eight exercises in political thought. Harmondsworth: Penguin Books.

Biesta, Geert. 1998. Pedagogy without Humanism: Foucault and the subject of education. Interchange 29 (1): $1-16$.

Biesta, Geert. 2005. Against learning. Reclaiming a language for education in an age of learning. Nordisk Pedagogik 25: 54-66.

Biesta, Geert. 2009. Good Education in an Age of Measurement: On the Need to Reconnect with the Question of Purpose in Education. Educational Assessment, Evaluation and Accountability 21 (1): 33-46.

Biesta, Geert. 2013. The Beautiful Risk of Education. Interventions: Education, Philosophy, and Culture. Boulder: Paradigm Publishers.

Biesta, Geert. 2016. The rediscovery of teaching: on robot vacuum cleaners, non-egological education and the limits of the hermeneutical world view. Educational Philosophy and Theory 48 (4): 374-392.

Bocchetti, André. 2015. Entre golpes e dispositivos: Foucault, Certeau e a constituição dos sujeitos. História Da Historiografia, 18 (September): 43-56.

Certeau De, Michel. 1968. La Loi Faure Ou Le Statut de l'enseignement Dans La Nation. Études (Décembre), 682-690.

Certeau De, Michel. 1969. Cuernavaca: Le Centre Interculturel et Mgr. Ivan Illich. Études, Octobre, 436-40.

Certeau De, Michel. 1971. Une Théorie Du Système d'enseignement. Études, Février, 292-93.

Certeau, De., and Michel. . 1979. Ecole et Cultures: Deplacer Les Questions. Genève: Université de Genève.

Certeau De, Michel. 1986a. Heterologies. Discourse on the Other. Minneapolis-London: University of Minnesota Press.

Certeau De, Michel. 1986b. Économies ethniques: pour une école de la diversité. Annales. Histoire, Sciences Sociales, 41 (4): 789-815.

Certeau, De., and Michel. 1987. Histoire Et Psychanalyse Entre Science Et Fiction. Paris: Gallimard.

Certeau, De., and Michel. 1988. The Practice of Everyday Life. Berkeley: University of California Press.

Certeau, De., and Michel. . 1991. Travel narratives of the french to Brazil: sixteenth to eighteenth centuries. Representations 33 (January): 221-226.

Certeau De, Michel. 1992. The writing of history. Translated by Tom Conley. New York: Columbia University Press.

Certeau, De., and Michel. 1996. Vocal Utopias: Glossolalias. Representations 56 (October): 29-47.

Certeau, De., and Michel. 1997a. Culture in the Plural. Minneapolis: Minnesota University Press.

CerteauMichel, De. 1997b. The Capture of Speech and Other Political Writings. Minneapolis: Minnesota University Press.

Certeau De, Michel. 2010. Lo Straniero o l'unione Nella Differenza. Milano: Vita e Pensiero, orig.ed. 1969.

CerteauMichel, De. 1978. Qu'est-ce qu'un séminaire? Esprit, 22 (23): 176-181.

Deligny, Fernand. 2017. Il gesto e l'ambiente. Cinema e pedagogia. Cosenza: Luigi Pellegrini.

Dussel, Ines. 2018. The digital classroom: A Historical Consideration on the Redesigning of the Contexts of Learning. In Making Education: Material School Design and Educational Governance, ed. Ian Grosvenor and Rosén L. Rasmussen, 173-196. Cham: Springer.

Freire, Paulo. 2005. Pedagogy of the oppressed. Translated by Myra Bergman Ramos. New York-London: Continuum.

Freud, Sigmund. 1991. Il perturbante, in Saggi sull'arte, la letteratura e il linguaggio. Torino: Bollati Boringhieri.

Frow, John. 1991. Michel De Certeau and the Practice of Representation. Cultural Studies 1 (5): 52-60.

Gordon, Mordechai, ed. 2001. Hannah Arendt and Education. New York-London: Routledge. 
Hodgson, Naomi, et al. 2017. Manifesto for a Post-Critical Pedagogy, 1st ed. Santa Barbara, CA: Punctum Books.

Jacomino, Baptiste. 2016. Le pédagogue et la mort: Penser l'éducation avec Michel De Certeau. Le Philosophoire 45 (1): 105-119.

Korsgaard, Morten T. 2020. Exemplarity and education: Retuning educational research. British Educational Research Journal 46 (6): 1357-1370.

Lewis, Tyson E. 2009. Education and the Immunization Paradigm. Studies in Philosophy and Education 28 (6): 485-498.

Lewis, Tyson E., \& Friedrich, Daniel. 2015. Educational States of Suspension. Educational Philosophy and Theory, 1-14.

Macrine, Sheila, et al. (eds.). 2010. Revolutionizing Pedagogy. Education for Social Justice within and beyond Global Neo-Liberalism. New York: Palgrave Macmillan US.

Marks, John. 1999. Certeau \& Foucault: The other and pluralism. Paragraph, 22(2,), 118-132.

Masschelein, Jan. \& Simons, Maarten. (2013). In Defence of the School: A Public Issue. Leuven: Education, culture \& Society Publishers. https://cygnus.cc.kuleuven.be/webapps/cmsmain/webui/_xy-11617 872_3-t_8iZAq0nv.

McLaren, Peter, et al. 2004. Teaching in and against the Empire. Teacher Education Quarterly 31 (1): 131-153.

Mclaren, Peter. 2020. The future of critical pedagogy. Educational Philosophy and Theory 52 (12): 1243-1248.

Resweber, Jean-Paul. 2007. Michel Foucault et Michel De Certeau. Le Portique Revue De Philosophie Et De Sciences Humaines, 13-14: 1-11.

Saltmarsh, Sue. 2015. Michel De Certeau, Everyday Life and Cultural Policy Studies in Education. In Education Policy and Contemporary Theory, edited by Kalervo N. Gulson, Matthew Clarke, and Eva Bendix Petersen, 1st ed., 27-38. London: Routledge.

Sandywell, Barry. 2004. The myth of everyday life: Toward a heterology of the ordinary. Cultural Studies $18(2-3): 160-180$.

Séradin, Jean-Yves. 2016. Penser Avec Michel De Certeau. Une Pédagogie Du Quotidien. Lyon : Chronique Sociale.

Séradin, Jean-Yves. 2017. L'inventivité pédagogique de Michel De Certeau. Educatio 6: 1-15.

Serres, Michel. 2014. Thumbelina: The culture and technology of millennials. Lanham: Rowman \& Littlefield.

Siapkas, Johannes. 2015. Ontología Del Otro: Reflexiones Sobre La Filosofía de Michel De Certeau. La Torre Del Virrey 1 (17): 48-59.

SimonsMasschelein, Maarten. 2010. Governmental, Political and Pedagogic Subjectivation: Foucault with Rancière. Educational Philosophy and Theory 42 (5-6): 588-605.

Swillens, Viktor, and Joris Vlieghe. 2020. Finding soil in an age of climate trouble: Designing a new compass for education with arendt and Latour. Journal of Philosophy of Education 54 (4): 1019-1031.

Thoilliez, Bianca. 2019. The craft, practice, and possibility of teaching. Studies in Philosophy and Education 38 (5): 555-562.

Vlieghe, Joris 2013. Experiencing im-potentiality: Bollnow and Agamben on educational meaning of School Practices. Studies in Philosophy and Education, 32(2), 1-15.

Vlieghe, Joris. 2014. Education in an age of digital technologies: Flusser, Stiegler, and Agamben on the Idea of the Posthistorical. Philosophy \& Technology 27 (4): 519-537.

Vlieghe, Joris. 2016. Education, digitization and literacy training: A historical and cross-cultural perspective. Educational Philosophy and Theory 48 (6): 549-562.

Vlieghe, Joris \& Zamojski, Piotr. 2019. Towards an Ontology of Teaching. Thing-centred Pedagogy, Affirmation and Love for the World. Cham: Springer.

Publisher's Note Springer Nature remains neutral with regard to jurisdictional claims in published maps and institutional affiliations. 